\title{
Vybrané pohledy na vztah české populace ke sportu
}

\section{Selected Perspectives on Attitudes of the Czech Population towards Sport}

\author{
Václav Stříteský \\ Fakulta podnikohospodářská Vysoké školy ekonomickév Praze
}

\begin{abstract}
Abstrakt
Článek zkoumá vztah české populace ke sportu, zabývá se třemi hlavními oblastmi projeveného zájmu o sport. Jedná se o aktivní provozování sportu, prímou návštěvu sportovních utkání a sledování sportovních televizních přenosů. Cílem analýzy je zjistit vybrané postoje české populace ke sportu včetně zhodnocení rozdilů podle pohlaví a věku. Druhým cílem je identifikovat nejoblíbenější druhy sportu $v$ České republice ve všech třech oblastech zájmu, tedy aktivního provozování, prímé účasti na utkáních a sledování televizních přenosů. Článek se zabývá rovněž srovnáním jednotlivých druhů sportu z hlediska relativní dominance aktivního nebo pasivního zájmu o daný sport a identifikuje jednotlivé skupiny navzájem souvisejících sportů. Analýzy jsou provedeny na datech vysoce akceptovaného výzkumného projektu Market \& Media \& Lifestyle - TGl, která pro účely tohoto článku zpřistupnila agentura Median. Výzkum je realizován na reprezentativním náhodném výběru pro českou populaci ve věku 12-79 let o velikosti výbèrového souboru pres 15 tis. respondentů.
\end{abstract}

\begin{abstract}
The paper explores attitudes of the Czech population towards sport. It deals with three main areas of people's interest expression in sport. They are active sport participation, attending sport matches and watching sports on television. The purpose of the research is to determine the attitudes of the Czech population towards sport, including the assessment of differences by gender and age. The second objective is to identify the most popular kinds of sport in the Czech Republic in all three areas of interest, i. e., the active participation, attending sport matches and watching sport broadcasts. The paper also deals with the comparison of the various kinds of sport in terms of the relative dominance of active or passive interest in sport. Different groups of related sports are identified. Analyses are based on the data of the research project Market \& Media \& Lifestyle - TGI, which was provided for the purpose of this research by Median agency. Research is carried out on a representative random sample of the Czech population aged 12-79 years. The sample size is over 15 thousand respondents.
\end{abstract}

Klíčová slova: sport, postoje ke sportu, druhy sportu, česká populace.

Key words: sport, attitudes towards sport, kind of sport, Czech population.

\section{ÚVOD}

Význam sportu pro společnost je spatřován v mnoha rovinách. Sekot (2008) uvádí pozitivní dopady sportu v ekonomické, kulturní a sociální oblasti, včetně celé řady konkrétních souvislostí (např. rozvoj turistického ruchu, sbližování národností a kultur apod.). Socializační úloha sportu je zmiňována v souvislosti s negativními dopady tzv. informační společnosti (Flemr, Valjent, 2010). Sport a kultura patří mezi základní způsoby trávení volného času, avšak výzkumy ukazují, že Češi tráví volný čas spiše relaxačně, typicky pak u obrazovek televize a počítače a posloucháním hudby (Šafr a Patočková, 2010). Někteří sociologové nahližejí na sport jako na společenský jev, jehož základním kritériem je podíl na rozvoji osobnosti, úloha ve společenské kultivaci způsobu života (Gabal a Rak, 1981). Z důvodů prríznivého vlivu sportu je často sledován vztah a postoje ke sportovním aktivitám zejména mezi mladou populací, např. studenty (Charvát, 2008; Mužík, 
Vodáková, P. 2010; Gajdošík, Baláš, 2012). Chybí zde pohled na postoje ke sportu napříč všemi věkovými skupinami včetně srovnání rozdílů vnímání sportu podle hlavních demografických charakteristik populace. Určité poznatky za českou populaci poskytují zčásti některé dostupné komerční výzkumné studie (např. PPM Factum, 2004; ING Bank, 2014).

Mezi kritizované aspekty sportu patří nejčastěji soudobá komercionalizace sportu, která se týká i marketingového využití sportu, např. sportovních celebrit v reklamních aktivitách firem (Tahal, 2014). S tím souvisí využití sportu jako mediálního obsahu, nebot' sportovní přenosy často patří mezi velmi atraktivní programovou nabídku televizních stanic, sportovní utkání poskytují obsah i pro další typy médií.

Vztah ke sportu je sice nejčastěji sledován z pohledu aktivního provozování sportu (viz Charvát, 2008; Gajdošík, Baláš, 2012; Zich, Unger, 1995; Thuot, 1995, Gošnik et al., 2002; Wyznikiewicz-Nawracala, 1998) avšak v mnoha ohledech je neméně zajímavá a důležitá také znalost vztahu a postojů populace k pasivnímu sportu. Ten má podobu prrímé účasti na sportovních utkáních nebo sledování sportu v médiích. Návštěvnost i sledovanost sportovních utkání má význam zvláště v ekonomické oblasti, avšak zejména navštěvování sportovních utkání souvisí s celou řadou dalších oblastí s celospolečenským významem (socializační úloha sportu, kultivace způsobu života, trávení volného času aj.). V odborných studiích zabývajících se sportem je oblast pasivního sportu opomíjena, není jí věnována dostatečná pozornost, jako v př́ípadě aktivního sportování. To je mj. dáno předpokládaným pozitivním vlivem fyzické aktivity obyvatel na jejich zdravotní stav, který je v řadě výzkumů diskutován (viz Haskell, 1996; Wannamethee, Shaper, 1992; Schmermund, 2004 a další). Mohla by se sice nabízet myšlenka, zda sledování sportu v televizi nemotivuje diváky k aktivnímu sportování, avšak dostupné výzkumy tento vztah nepotvrzují. Naopak naznačují větší sklon k obezitě při pravidelném sledování televize (viz Hamer, Weiler, Stamatakis, 2014).

Vzhledem $\mathrm{k}$ výše uvedeným skutečnostem bylo cílem provedeného výzkumu poskytnout komplexní pohled na vztah a postoje české populace ke sportu, včetně identifikace nejoblíbenějších druhů sportu, a to ve všech třech uvedených rovinách, tedy aktivního sportování, prímé účasti na sportovních utkáních a sledování sportu v médiích. Výzkum zároveň zkoumá odlišnosti v postojích podle pohlaví a věku.

\section{METODIKA}

Výzkum je založen na analýze dat agenturní databáze Market \& Media \& Lifestyle - TGI (dále jen MML-TGI), kterou pro účely tohoto výzkumu laskavě poskytla společnost Median. V rámci tohoto rozsáhlého projektu je sledováno spotřební chování (přes 300 druhů výrobků a služeb, přes 3000 jednotlivých značek), mediální chování (přes 400 médií) a životní styl respondentů. Pro účely tohoto článku byly k analýze vybrány relevantní výzkumné otázky týkající se sportovních aktivit populace a postojů ke sportu. Jak uvádí realizátor výzkumu Median (2014), projekt je vysoce akceptovaným zdrojem údajů $v$ oblasti cíleného marketingu, reklamy a mediálního plánování. Jedná se o kontinuální dotazníkový výzkum na reprezentativním náhodném výběru o velikosti minimálně 15 tis. respondentů (pro zkoumané období je pracováno s výběrem o velikosti 15008 respondentů). Metodou výběru je náhodný stratifikovaný výběr, používá se technika osobního dotazování. Výsledná data se statisticky převažují. Výběrový soubor tvoří respondenti ve věku 12-79 let. Podobný výzkum probíhá v dalších více než 60 zemích světa. Ke statistickým analýzám byl poskytnut datový soubor za rok 2012. Datový soubor byl poskytnut v rámci dlouhodobé spolupráce agentury Median s Fakultou podnikohospodářskou Vysoké školy ekonomické v Praze.

Pro analýzy dat byl využit analytický software Data Analyzer ver. $4.70 \mathrm{~d}$ a tabulkový procesor Microsoft Excel ver. 2007.

V analýzách dat je pracováno s relativními četnostmi (sloupcovými procenty) a indexy afinity. Index afinity poměřuje výskyt jevu v dané cílové skupině vůči jeho výskytu v celé populaci. Pokud je hodnota vyšší než 100, značí o nadprůměrném výskytu daného jevu v této cílové skupině, pokud 
naopak menší než 100, vyjadřuje podprůměrný výskyt jevu oproti populaci. Index tak slouží pro snadnou orientaci při vyhodnocování rozdílů mezi cílovými skupinami, např. muži a ženami.

K vyhodnocení souvislostí mezi proměnnými byl využit chí-kvadrát test nezávislosti. Ten při velkých výběrových souborech může vycházet „statisticky významně“ i pro malé rozdíly. Statistická významnost diferencí byla ověřována pomocí testů rovnosti středních hodnot. Konkrétně se jednalo o testy pro nezávislé výběry, stř̌ední hodnotu zde reprezentovaly relativní četnosti zkoumaného jevu v definované populaci (cílové skupině). Použity byly tzv. testy homogenity binomických rozdělení.

Pro identifikaci skupin druhů sportu, které mají podobné charakteristiky s dopadem na oblibu jejich provozování, byla zapojena faktorová analýza. Jednalo se o metodu hlavních komponent s nastavením rotace faktorů metodou Varimax.

\section{VÝSLEDKY}

\section{Aktivní sport a sportovní diváctví}

Pokud jde o aktivní př́stup české populace ke sportu (výzkumná otázka „Jak často jste se v průběhu 6 měsíců věnoval/a aktivní sportovní činnosti?), alespoň 1-2× za měsíc se sportu věnuje zhruba třetina obyvatel ve věku 12-79 let. Jestliže za pravidelnou aktivitu považujeme vykonávání sportu alespoň jednou týdně, jedná se pouze o necelých $23 \%$ populace. Více než $40 \%$ Čechů deklaruje, že žádný sport téměř nebo vůbec neprovozuje (viz Tab. 1).

Tabulka 1: Aktivní sportovní činnost české populace

\begin{tabular}{|l|c|c|c|c|c|}
\hline \multirow{2}{*}{$\begin{array}{l}\text { Jak často jste se v průb. 6 měs. věn. aktivní } \\
\text { sportovní činnosti? }\end{array}$} & \multicolumn{2}{|c|}{ Muži } & \multicolumn{2}{c|}{ Ženy } & Celkem \\
\cline { 2 - 6 } & Sl. \% & Index & Sl. \% & Index & Sl. \% \\
\hline Denně & 2,1 & 120,5 & 1,4 & 79,8 & 1,7 \\
\hline $3-4 \times$ za týden & 6,6 & 118,0 & 4,6 & 82,3 & 5,6 \\
\hline $1-2 \times$ za týden & 16,7 & 109,3 & 13,9 & 90,9 & 15,2 \\
\hline $1-2 \times$ za měsíc & 12,8 & 111,9 & 10,1 & 88,3 & 11,5 \\
\hline Méně často & 18,3 & 105,2 & 16,5 & 94,9 & 17,4 \\
\hline Nikdy/téměř nikdy & 38,1 & 88,4 & 48,0 & 111,4 & 43,1 \\
\hline Neuvedeno & 5,4 & 99,1 & 5,5 & 100,8 & 5,5 \\
\hline Celkem & 100,0 & 100,0 & 100,0 & 100,0 & 100,0 \\
\hline
\end{tabular}

Vztah k aktivnímu sportu se statisticky významně liší mezi muži a ženami $\left(\chi^{2}=173,2\right.$ při 5 stupních volnosti, $\mathrm{p}<0,05)$. Muži oproti ženám sportují častěji. Chí-kvadrát test často poskytuje při rozsáhlých výběrových souborech statisticky významné výsledky i při relativně malých rozdílech. Proto byly rozdíly v odpovědích mužů a žen dále testovány pomocí testu homogenity binomických rozdělení. Test prokázal opět statisticky významné rozdíly mezi muži a ženami ve všech kategoriích odpovědí týkajících se frekvence sportování. Ve všech případech lze i na $1 \%$ hladině významnosti zamítnout nulovou hypotézu o shodě středních hodnot.

Výsledky analýzy prokázaly očekávaný vliv věku na vykonávání sportovních aktivit. Alespoň 1-2× týdně sportuje $41,1 \%$ Čechů do 29 let, $24 \%$ ve věku $30-49$ let a pouze $9,0 \%$ ve věku 50 a více let. Test homogenity více binomických rozdělení prokázal statisticky významné odlišnosti ve sportování věkových skupin na $1 \%$ hladině významnosti. Střední hodnoty se liší zejména pro denní provozování sportu u nejmladších věkových skupin. Oproti 1,7\% populace se mladí lidé do 19 let každodenně věnují sportu téměř z $6 \%$. Další statisticky významné diference jsou pozorovatelné v případě nízké nebo žádné sportovní aktivity, kdy podíl významně roste s přibývajícím věkem. Pouze $18 \%$ Čechů do 19 let se sportu téměř nebo vůbec nevěnuje, v případě věkové skupiny nad 70 let je to $76 \%$. U všech věkových skupin byla v tomto případě zamítnuta hypotéza o shodě středních hodnot na $1 \%$ hladině významnosti. Věkové skupin se významně odlišují i v pravidel- 
ném sportování alespoň 1-2× týdně. Podíl opět klesá s rostoucím věkem. Podobné chování pouze vykazují věkové kategorie 20-29 let a 30-39 let, kde hypotéza o rovnosti středních hodnot nebyla zamítnuta ani na $5 \%$ hladině významnosti.

Vztah populace ke sportu vyjadřuje také návštěvnost sportovních utkání (viz. Tab 2.). Alespoň někdy za posledních 6 měsíců (součet odpovědí v intervalu „denně“ až „méně často než 1-2× za měsíc“) deklarovalo návštěvu sportovních utkání 45 \% Čechů. Aktivnějšími návštěvníky jsou opět spíše muži než ženy ( 57 \% mužů oproti 31 \% žen). Rozdíly jsou statisticky významné $\left(\chi^{2}=995,4\right.$ prri 5 stupních volnosti, $\left.\mathrm{p}<0,05\right)$. Test homogenity binomických rozdělení prokázal statisticky významné rozdíly mezi muži a ženami pro všechny kategorie návštěvnosti sportovních utkání na $1 \%$ hladině významnosti, kromě frekvence 3-4× za týden. Zde lze hypotézu o shodě středních hodnot zamítnout pouze na hladině významnosti $5 \%$.

Tabulka 2: Návštěva sportovních utkání

\begin{tabular}{|l|c|c|c|c|c|}
\hline \multirow{2}{*}{$\begin{array}{l}\text { Jak často jste se v průb. } 6 \text { měs. věn. návštěvě } \\
\text { sportovních utkání? }\end{array}$} & \multicolumn{2}{|c|}{ Muži } & \multicolumn{2}{c|}{ Ženy } & Celkem \\
\cline { 2 - 6 } & Sl. \% & Index & Sl. \% & Index & Sl. \% \\
\hline Denně & 0,3 & 151,8 & 0,1 & 49,1 & 0,2 \\
\hline $3-4 \times$ za týden & 1,4 & 118,7 & 0,9 & 81,6 & 1,1 \\
\hline $1-2 \times$ za týden & 7,3 & 144,5 & 2,8 & 56,3 & 5,0 \\
\hline $1-2 \times$ za měsíc & 19,1 & 141,7 & 8,0 & 59,1 & 13,5 \\
\hline Méně často & 29,0 & 115,7 & 21,2 & 84,6 & 25,1 \\
\hline Nikdy/téměr̆ nikdy & 37,4 & 76,5 & 60,2 & 123,1 & 48,9 \\
\hline Neuvedeno & 5,5 & 90,2 & 6,7 & 109,6 & 6,1 \\
\hline Celkem & 100,0 & 100,0 & 100,0 & 100,0 & 100,0 \\
\hline
\end{tabular}

Aktivní zájem o sport v podobě návštěvy sportovních utkání je opět statisticky významně determinován věkem. S rostoucím věkem zájem o návštěvu sportovních utkání klesá. Alespoň někdy za 6 měsíců navštíví sportovní utkání 57,5 \% Čechů do 29 let, 48,5\% ve věku 30-49 let a 33,4 \% ve věku 50 a více let. Zájem o sport projevený v návštěvě utkání je však i mezi staršími lidmi vyšší, než je tomu v př́ípadě aktivního provozování sportu. Test homogenity binomických rozdělení prokázal statisticky významnou odlišnost v častější návštěvnosti sportovních utkání u lidí do 29 let $(\mathrm{p}<0,01)$. Pro střední věkovou skupinu je prokázána statisticky významná odlišnost v návštěvě sportovních utkání méně často než $1-2 \times$ za měsíc a v kategorii žádných návštěv $(\mathrm{p}<0,01)$. Nejstarší populace se statisticky významně liší ve všech kategoriích návštěvnosti sportovních utkání $(\mathrm{p}<0,01)$.

Jako pasivní vyjádření zájmu o sport v podobě sportovního diváctví bylo v analýzách zkoumáno sledování sportovních událostí v médiích, konkrétně pak televizi.

O sport jako téma v médiích se zajímá 41,4\% české populace ve věku 12-79 let. Muži deklarují zájem o sport mnohem častěji než ženy (61,7 \% mužů, 21,5 \% žen). Chí-kvadrát test prokázal rozdíl jako statisticky významný $\left(\chi^{2}=2496,0\right.$ při 1 stupni volnosti, $\left.p<0,01\right)$. Korelační koeficient zde nabývá hodnoty 0,4 . Stejně tak test homogenity binomických rozdělení prokázal statisticky významný rozdíl v zájmu o sport mezi muži i ženami na $1 \%$ hladině významnosti.

$\mathrm{S}$ rostoucím věkem je pozorovatelný nižší zájem o sport $\mathrm{v}$ médiích, ale pokles není nijak dramatický (44,6 \% populace do 29 let, 41,7 \% ve věku $30-49$ let a $38,9 \%$ ve věku 50 a více let). Test homogenity binomických rozdělení prokázal statisticky významný rozdíl pouze u nejmladší věkové kategorie do 29 let a starší věkové kategorie 50 a více let $(\mathrm{p}<0,01)$. U střední věkové kategorie nelze zamítnout hypotézu o shodě středních hodnot ani na $5 \%$ hladině významnosti.

Pokud jde o sledování sportovních témat v televizi, na jeho oblibu v české populaci a rozdíly podle pohlaví ukazuje Tab. 3 . 
Tabulka 3: Sledování sportu v televizi

\begin{tabular}{|l|r|r|r|r|c|}
\hline \multirow{2}{*}{ Zajímáte se o sport v televizi? } & \multicolumn{2}{|c|}{ Muži } & \multicolumn{2}{c|}{ Ženy } & Celkem \\
\cline { 2 - 6 } & Sl. \% & \multicolumn{1}{|c|}{ Index } & Sl. \% & Index & Sl. \% \\
\hline Speciálně si vybírám k sledování & 27,9 & 175,3 & 4,2 & 26,1 & 15,9 \\
\hline Obyčejně se snažím sledovat & 18,9 & 150,9 & 6,3 & 50,1 & 12,5 \\
\hline Občas sleduji & 18,0 & 98,6 & 18,5 & 101,4 & 18,2 \\
\hline Nikdy nesleduji & 35,2 & 66,0 & 71,1 & 133,4 & 53,3 \\
\hline Celkem & 100,0 & 100,0 & 100,0 & 100,0 & 100,0 \\
\hline
\end{tabular}

Alespoň občas sleduje sport v televizi téměř $47 \%$ české populace ve věku 12-79 let. V př́ipadě sledování televize jsou patrné významné rozdíly v preferenci sportovních témat mezi muži a ženami. Alespoň občas sleduje sport v televizi 65 \% mužů, avšak pouze $29 \%$ žen. Jak vyplývá z Tab. 3., necelá třetina mužů si dokonce sport k sledování v televizi speciálně vybírá (oproti 4,2\% žen). Chí-kvadrát test prokázal téměř ve všech kategoriích sledování televize statisticky významný rozdíl dokonce na $0,1 \%$ hladině významnosti, kromě odpovědi „občas sleduji“. V občasném sledování sportu v televizi se muži a ženy neliší, relativní četnosti lze považovat za shodné. Stejné výsledky nabízí i test homogenity binomických rozdělení. Pouze pro občasné sledování sportu nelze zamítnout hypotézu o shodě relativních četností $(p>0,05)$.

Vliv věku na sledování sportu $\mathrm{v}$ televizi není tolik zřetelný. O něco více sledují sport mladší lidé, zejména pak v kategorii do 29 let (48,8\% sleduje sport alespoň občas, ostatní věkové kategorie ze 46 \%). Statisticky významné diference prokázal test homogenity binomických rozdělení pouze u nejstarší věkové skupiny v př́ipadě jakékoli míry sledování televize, kromě nesledování, kde se shoduje se střední věkovou skupinou. Střední věková kategorie se statisticky významně liší v občasném sledování televize, nejmladší věková kategorie statisticky významně méně zastupuje nezájem o sledování sportovních pořadů.

Míra aktivního či pasivního zájmu o sport (sportovního diváctví) se bude přirozeně lišit podle typu sportovní aktivity. Analýza v rámci tohoto výzkumu zahrnovala rovněž srovnání 49 různých sportů z pohledu dominance diváctví nebo aktivního zájmu o daný sport mezi českou populací. Za každý jednotlivý sport byl spočítán podíl aktivních sportovců, návštěvníků utkání a televizních diváků na celkovém počtu zájemců o daný sport. Zájemcem je zde chápán jedinec, který se o daný sport zajímá alespoň jedním z uvedených třech způsobů (aktivní vykonávání sportu, přímé návštěvy utkání nebo sledování sportovních přenosů v televizi). V této analýze je tedy abstrahováno od velikosti zastoupení sportu v populaci, hodnotí se pouze podíl zájemců skutečně provozujících daný sport mezi všemi zájemci o konkrétní druh sportu.

Největší podíl aktivních sportovců mezi zájemci o daný druh sportu mají tyto sporty:

- turistika $(89,9 \%)$,

- kolečkové bruslení $(86,4 \%)$,

- fitness/posilování (84,5\%),

- bowling $(81,8 \%)$.

V České republice neexistují žádné sporty, u kterých by mezi zájemci dominovali ti, kteři přímo navštěvují utkání. Sporty s největším podílem přímé účasti na sportovních utkáních jsou tyto:

- fotbal $(29,5 \%)$,

- nohejbal $(24,0 \%)$,

- ragby (23,5\%),

- lední hokej (21,4 \%). 
Mnoho sportů se vyznačuje převahou zájemců s pasivním sledováním utkání v televizních přenosech, kdy pouze minoritní část zájemců daný sport aktivně vykonává. Dủvodem může být mj. finanční náročnost provozování takového sportu, popř. obecně silná mediální podpora. Jedná se zejména o tyto sporty:

- krasobruslení $(96,5 \%)$,

- automobilové závody (93,1\%),

- lední hokej $(92,7 \%)$,

- atletika $(90,2 \%)$.

Výsledky této analýzy ukazují, které sporty v České republice mají spíše aktivní nebo pasivní charakter.

\section{Oblíbené sporty v České republice}

Jedním z výzkumných cílů bylo identifikovat nejoblíbenější sporty v české populaci ve všech tř̌ech sledovaných rovinách, tedy z pohledu aktivního provozování, přímých návštěv utkání a sledování sportovních televizních přenosů.

Nejoblíbenější sporty v České republice podle způsobu projeveného zájmu o daný sport zobrazuje Tab. 4. Obliba je vyjádřena podílem v populaci (přesněji v populaci ve věku 12-79 let).

Tabulka 4: Nejoblíbenější sporty v České republice

\begin{tabular}{|l|c|l|c|l|l|}
\hline Provozované sporty & Sl. \% & Navštěvovaná utkání & Sl. \% & Sledované sporty v TV & Sl. \% \\
\hline Cyklistika/cykloturistika & 21,8 & Fotbal & 11,3 & Lední hokej & 39,6 \\
\hline Plavání & 20,4 & Lední hokej & 9,2 & Fotbal & 33,2 \\
\hline Turistika & 16,4 & Tenis & 2,7 & Autom. závody & 20,4 \\
\hline Bowling & 9,9 & Autom. závody & 2,7 & Tenis & 19,7 \\
\hline Kolečkové bruslení & 9,8 & Atletika & 2,2 & Atletika & 19,6 \\
\hline
\end{tabular}

Z analýzy vyplývá, že není žádný vztah mezi oblíbenými sporty, které Češi provozují, a sporty, které přímo navštěvují či sledují v televizi. Mezi nejmasověji provozované sporty patří v ČR cyklistika, plavání a turistika. Naopak nejméně provozované sporty jsou ragby, americký fotbal a kriket. O ně jeví zájem pouze $0,1-0,2 \%$ obyvatelstva ve věku 12-79 let. Významnějšími sporty jsou rovněž lyžování (sjezd), fitness/posilování a fotbal. Těmto sportovním aktivitám se věnuje v ČR 8-9\% obyvatel. Dostupný sport - běh - je populární jen u 6,7\% populace. Zastoupení nejsledovanějších sportů jak přímo na utkání, tak v televizi, je podobné.

Obliba sportovních aktivit se bude lišit podle pohlaví. Jelikož aktivně provozované sporty v populaci poměrně vybočují a první tři jsou významně více zastoupeny oproti ostatním, je očekávatelné, že minimálně v prvních třech druzích sportu se budou muži i ženy shodovat. Naopak odlišné preference lze očekávat u sledovaných sportů, at již aktivní účastí na utkáních, tak sledováním televizních přenosů. Tab. 5. ukazuje sporty oblíbené mezi muži.

Tabulka 5: Nejoblíbenější sporty mezi českými muži

\begin{tabular}{|l|c|l|c|l|c|}
\hline Provozované sporty & Sl. \% & Navštěvovaná utkání & Sl. \% & Sledované sporty v TV & Sl. \% \\
\hline Cyklistika/cykloturistika & 21,6 & Fotbal & 18,4 & Fotbal & 56,9 \\
\hline Plavání & 18,1 & Lední hokej & 13,9 & Lední hokej & 56,5 \\
\hline Turistika & 15,4 & Autom. závody & 4,4 & Autom.závody & 33,5 \\
\hline Fotbal & 15,2 & Tenis & 3,6 & Tenis & 26,8 \\
\hline Bowling & 10,6 & Cyklistika/cykloturistika & 2,8 & Atletika & 24,8 \\
\hline
\end{tabular}


Z provozovaných sportů mezi muži jsou sice první tři nejoblíbenější shodné s celkovou populací, muži se však rovněž relativně často věnují fotbalu. Ten je zároveň nejsledovanějším sportem jak přímo na utkáních, tak v televizi. Mezi nejméně provozované sporty patří u českých mužů ragby, krasobruslení a kriket. Z hlediska indexu afinity lze identifikovat čistě maskulinní sporty, tedy sporty, o něž mají muži nadprůměrný zájem oproti celé populaci. Nejvyšší hodnoty indexu afinity dosahují u mužů tyto provozované sporty:

- nohejbal (191,6),

- fotbal $(190,3)$,

- lední hokej $(185,2)$,

- florbal $(167,8)$,

- rybaření $(166,7)$.

Mezi typicky mužská sledovaná sportovní témata patří motorismus, motocykly, fotbal a automobilové závody.

Tabulka 6: Nejoblíbenější sporty mezi českými ženami

\begin{tabular}{|l|c|l|c|l|c|}
\hline Provozované sporty & Sl. \% & Navštěvovaná utkání & Sl. \% & Sledované sporty v TV & Sl. \% \\
\hline Plavání & 22,7 & Lední hokej & 4,5 & Krasobruslení & 29,5 \\
\hline Cyklistika/cykloturistika & 21,9 & Fotbal & 4,3 & Lední hokej & 23,0 \\
\hline Turistika & 17,4 & Tanec & 2,5 & Tanec & 18,5 \\
\hline Kolečkové bruslení & 11,8 & Tenis & 1,8 & Atletika & 14,5 \\
\hline Tanec & 10,6 & Aerobik & 1,7 & Tenis & 12,6 \\
\hline
\end{tabular}

Výsledky za ženskou část populace uvádí Tab. 6. Složení prvních třech nejoblíbenějších sportů, které ženy provozují, je opět podobné celkové populaci. Více žen se však věnuje plavání než cyklistice. Mezi oblíbené sporty pak patři kolečkové bruslení a tanec. Naopak mezi nejméně provozované sporty patři u žen - stejně jako v populaci - ragby, americký fotbal a kriket. Velmi zřídka se ženy věnují pozemnímu hokeji a nohejbalu (0,2 \%). Pro ženy je příznačný velmi nízký zájem o prímou účast na sportovních utkáních. Mezi nejnavštěvovanější patří podobné sporty jako u mužů - tedy lední hokej a fotbal. Avšak oproti téměř pětině mužů, kteří alespoň jednou v roce navštíví fotbalový zápas, a 14 \% mužůn, kteří navštíví utkání v ledním hokeji, se jedná pouze o 4,5 \% žen s přímou účastí na utkáních těchto nejatraktivnějších sportů. Menší zájem je patrný rovněž u sledování televizních přenosů. Nejoblíbenějším televizním sportem je u žen krasobruslení. V televizi ho však zhlédne necelá třetina. Stejně jako u mužů je velmi oblíbeným lední hokej, na který se však v televizi dívá pouze $23 \%$ žen (oproti $56,5 \%$ mužů).

Podle vypočtených indexů afinity lze také v případě žen identifikovat typické femininní sporty. Patři mezi ně zejména:

- $\operatorname{aerobik}(183,7)$,

- jóga $(176,7)$,

- jezdectví $(150,9)$,

- $\operatorname{tanec}(149,9)$

- gymnastika $(144,8)$.

Mezi typicky ženská sledovaná sportovní témata patří krasobruslení, tanec, aerobik a gymnastika.

Pomocí faktorové analýzy (metoda hlavních komponent, rotace metodou Varimax) byly identifikovány rámcové skupiny sportů, které Češi provozují společně a lze tak u nich nalézt podobné rysy. Analýza zahrnovala 49 sportů, výstupem bylo 14 faktorů. Výsledky jsou pouze orientační, nebot faktorová analýza dokázala vysvětlit pouze $46 \%$ rozptylu. Některé faktory sytí pouze jeden 
druh sportu. Z výsledků jsou tak uvedeny pouze faktory s více sporty, které dosáhly vyšších hodnot faktorové zátěže (alespoň 0,5 , popř. mezi 0,4 a 0,5 ).

$\mathrm{Z}$ výsledků analýzy lze identifikovat tyto skupiny souvisejících sportů:

1. šipky, kulečník, šachy, rybaření, popř. stolní tenis (faktorová zátěž pouze 0,43).

2. lyžování (běh), cyklistika/cykloturistika, plavání, lyžování (sjezd), turistika.

3. tenis, popŕ. volejbal $(0,45)$.

4. lední hokej, fotbal, florbal, popř. pozemní hokej $(0,41)$.

5. krasobruslení, gymnastika.

6. motorismus, motocykly (bliží se sem také extrémní sporty).

7. bojové sporty, box.

8. baseball/softbal, americký fotbal, házená.

9. atletika, běh.

10. golf, jezdectví.

11. ragby, nohejbal.

Zbylé tři faktory jsou již reprezentovány převážně jedním sportem. Dvanáctý faktor sytí zejména tanec, další faktor automobilové závody, popř. snowboarding, poslední pak kategorie „ostatní sporty“.

Pro některé faktory se nabízí poměrně jednoznačná interpretace, např. skupina 1 zastupuje pro ČR typické „hobby sporty“, ve skupině 2 jde o reprezentanty rekreačních sportů, skupina 4 reprezentuje oblíbené mužské sporty, skupina 6 motoristické či adrenalinové sporty, skupina 7 kontaktní sporty atp. Výsledky rámcově naznačují zájmově homogenní skupiny sportů v České republice.

\section{DISKUSE}

Z výsledků provedených analýz vyplývá, že se sportu alespoň občas věnuje zhruba polovina Čechů ve věku 12-79 let. Pokud za aktivní sport považujeme pravidelnou aktivitu, vyznívají výsledky ještě méně příznivě. Alespoň 1-2× měsíčně deklarovalo provozování sportu 34 \% Čechů, týdně pouze $23 \%$. Jedná se o menší podíl, než uvádějí některé starší i novější výzkumné studie (např. PPM Factum, 2004; ING Bank 2014). Je však nutné upozornit, že uvedené dva výzkumy probíhaly na řádově menších velikostech výběrových souborů (převážně stovky) $\mathrm{s}$ odlišnou strukturou výběrového souboru. Dále výzkumná studie PPM Factum probíhala na populaci 15+, ING Bank dokonce pouze na dospělé populaci. Komerční výzkumy jsou rovněž mnohdy realizovány na on-line panelech respondentů, kdy zobecnění na celou českou populaci může být sporné. Současně znění výzkumných otázek nebylo zcela shodné. Výzkumná otázka analyzovaných dat MML-TGI zkoumala sportovní aktivitu za posledních 6 měsíců, nikoli celý rok. I tato skutečnost se může odrážet v nižších podílech aktivních sportovců. Ve shodě s předchozími studiemi vycházejí menší rozdíly v provozování sportu mezi muži a ženami. Ženy provozují sport méně často, diference však nejsou vysoké, byt vycházejí jako statisticky významné. Výzkum dále potvrdil souvislost mezi aktivním vykonáváním sportu a věkem. S rostoucím věkem se sportovní aktivita obyvatel postupně snižuje, a to poměrně skokově ze $41 \%$ mladých do 29 let na $9 \%$ starších 50 let. Tyto výsledky jsou v souladu se starší výzkumnou studií PPM Factum (2004). Klesající tendence však zcela neplatí pro pasivní zájem o sport, zejména pak sledování sportovních televizních pořadů, které je poměrně vysoce zastoupeno i mezi seniorskou generací.

Pasivní vztah ke sportu vyjádřen zájmem o sledování sportovních utkání se liší u přímé návštěvnosti utkání a sledování televizních přenosů. V obou případech jsou aktivnější muži než ženy, což potvrzuje výsledky předchozích studií. V české populaci 12-79 let navštěvuje alespoň občas sportovní utkání 45 \% Čechů, přímou návštěvnost deklarovalo téměř 60 \% mužů. Sledování televizních přenosů je v České republice ještě oblíbenější, jedná se o $47 \%$ populace, opět zejména muže (64\%). 28 \% mužů si dokonce sportovní pořady k sledování v televizi speciálně 
vybírá. S rostoucím věkem mírně klesá zájem o sledování sportu, významněji však u přímé účasti na utkáních. U mladší a stř̌ední věkové skupiny převažuje přímá návštěvnost sportovních utkání nad sledováním přenosů v televizi (týká se však počtu osob pro alespoň občasné sledování či účast, většina Čechů totiž navštěvuje sportovní utkání méně než $1 \times$ měsíčně). Naopak starší generace Z větší části sleduje sportovní utkání v televizi než přímo.

Aktivní sportování a sportovní diváctví se velmi liší podle druhu sportu. Analýza 49 druhů sportu ukazuje, že dostupné sporty pro rekreační vyžití jsou naopak velmi málo atraktivní pro jejich přímé či televizní sledování. Jedná se očekávatelně o sporty jako je turistika, kolečkové bruslení, fitness a bowling. Ale nižší podíl zájmu v podobě diváctví ve srovnání s aktivním provozováním sportu je pozorovatelné také u zájemců o plavání nebo šachová utkání. Relativně vysoký zájem o př́mé sledování utkání mají mezi zájemci týmové sporty jako je fotbal, nohejbal, ragby a lední hokej. Pro zájemce o určitý druh sportu je naopak drtivě převažující sledování televizních přenosů u krasobruslení, automobilových zápasů, ledního hokeje a atletiky.

Významná část výzkumu se zabývala atraktivitou jednotlivých sportů hodnocenou podle podílu v populaci. Analyzována byla atraktivita ve třech dimenzích, konkrétně aktivního sportu, prrímé účasti na utkáních a sledování televizních přenosů.

K aktivně provozovaným sportům patří v České republice spíše rekreační sporty, které jsou zároveň lidem snadno dostupné a mnohdy je nemusí vykonávat s cílem čistě sportovního záměru. Výsledky nejsou v rozporu s předchozími studiemi. Jedná se zejména o cyklistiku, plavání a turistiku, prričemž více žen dává přednost plavání před cyklistikou. Tyto tři sporty lze označit za masově provozované (mainstreamové) sporty v České republice. Češi nejčastěji př́imo navštěvují fotbalová a hokejová utkání. Jedná se zejména o muže, mezi kterými jsou návštěvy těchto utkání velmi oblíbené. Přímá návštěvnost těchto dvou sportů u mužů jednoznačně převažuje. U žen se návštěvy utkání rozprostírají rovnoměrně, nepřevažuje tak významně některý ze sportů, jako je tomu u mužů, Relativně nejvíce žen se účastní jako divák utkání v ledním hokeji a ve fotbale. Rády ale také sledují tanec. Pro televizní sportovní přenosy vychází jako nejoblíbenější sport v rámci celé české populace lední hokej a fotbal, následované automobilovými závody. Jelikož sportovní přenosy sleduje významně více mužů než žen, odpovídají tyto sporty právě mužskému publiku. Mezi muži je však v televizi mírně oblíbenější fotbal než lední hokej. Ženy naopak sledují zejména krasobruslení, lední hokej a tanec.

Z hlediska aktivního provozování sportu odkryla faktorová analýza 14 rámcových skupin sportů, které spolu v rámci každé skupiny určitým způsobem souvisejí a jako celek jsou pro určité skupiny populace atraktivní. Jelikož většina Čechů nevykonává více sportů, jedná se pouze o orientační třídění, které však poskytuje zajímavý pohled na velmi širokou oblast sportovních aktivit.

\section{ZÁVĚRY}

Reprezentativní výzkum na výběrovém souboru více než 15 tis. respondentů ve věku 12-79 let potvrzuje některé výsledky předchozích studií realizovaných na českém trhu. Rezervovanější výsledky poskytuje pohled na aktivní pravidelnou sportovní aktivitu české populace, kdy provozování sportovních aktivit 1-2× týdně deklarovalo pouze $23 \%$ dotázaných. V projekci se jedná zhruba o 2012 tis. obyvatel. Alespoň 1-2× měsíčně se sportu věnuje 3031 tis. obyvatel. Výsledky analýz potvrzují souvislost sportovní aktivity a věku. Statisticky významné jsou rovněž rozdíly podle pohlaví, avšak v př́ípadě aktivního sportu nejsou tolik pozorovatelné, jako při pasivním sledování sportovních přenosů či přímé účasti na utkáních. Výzkum potvrdil dlouhodobou atraktivitu nejčastěji provozovaných sportů, mezi které patří cyklistika, plavání a turistika. Mezi nejsledovanější sportovní utkání přímo i v televizi patří tradičně lední hokej a fotbal. Odlišné preference sledovaných sportů mají muži a ženy. Ženy jsou oproti mužům významně méně aktivní ve sledování sportovních utkání, at již jde o přímou účast, tak sledování televizních přenosů. Provedené analýzy agenturních dat MML-TGI přinesly přehled nejoblíbenějších sportů s aktivním a pasivním 
zájmem české populace. Identifikovány také byly rámcové skupiny sportů s vnitřní homogenitou podle zájmu o jejich provozování.

Výsledky analýzy poskytují užitečný pohled na sportovní aktivitu české populace a popularitu vybraných druhů sportu. Vedle aktivního provozování sportu je analyzována také oblast sportovního diváctví a sledování sportovních přenosů v televizi. Uvedená zjištění mohou být využitelná jak při cílené podpoře aktivního sportu, tak pořádání divácky atraktivních sportovních událostí. Poznatky této studie jsou zajímavé rovněž pro marketing, který sport a sportovní události využívá v komunikačních aktivitách. Neméně významné jsou v této oblasti znalosti obsahových preferencí mediálního publika, které předurčují atraktivitu sportovních přenosů. Přestože celospolečenský význam sportu je nepopiratelný, komplexnější výzkumné studie monitorující vztah české populace ke sportu a sportovnímu diváctví v podstatě chybí. Výsledky provedené analýzy tak doplňují a rozšiřují dosavadní poznatky dostupných studií o další užitečné pohledy. V následujících výzkumech by bylo žádoucí rozšiřǐit tyto pohledy o mezinárodní srovnání a rovněž identifikaci dalších faktorů ovlivňujících vztah jedinců ke sportu.

\section{Literatura}

Flemr, L., Valjent, Z. (2010). Socializace sportem. Studia sportiva, 4 (1), 71-87.

Gabal, I., Rak, V. (1981). Sport a sportovní diváctví: Některé poznatky z výzkumu životního způsobu Pražanů. Sociologický Časopis, 17 (2), 178-196.

Gajdošík, J., Baláš, J. (2012) Zájem o pohybové aktivity u studentů medicíny Univerzity Karlovy. Studia sportiva, 6(2), 62-69.

Gošnik, J., et al. (2002). Sport experience of undergraduate students. Proceedings Book, 3rd ISC, Opatija.

Hamer, M., Weiler, R., Stamatakis, E. (2014). Watching sport on television, physical activity, and risk of obesity in older adults. BMC Public Health, 14(1), 10.

Haskell, W. L. (1996). Physical activity, sport, and health: Toward the next century. Research Quarterly for Exercise and Sport, 67(3), 11.

Charvát, M. (2008). Sledování postojů a motivů mládeže ke sportovním pohybovým aktivitám. Studia sportiva, 2(2), 83-90.

ING Bank (2014). Sportovní aktivity Čechů. Dostupné z < http://www.ingbank.cz/files/svet-sporeni/2014-10-30-cesi-sport_ infografika.pdf>

Median (2014). Market Media Lifestyle (MML-TGI). Dostupné $\mathrm{z}<$ http://www.median.cz/index.php?lang=cs\&page=1\&sub=1>

Mužík, V., Vodáková, P. (2010). Sonda do školní pohybové aktivity dětí mladšího školního věku. In Řehulka, E. (Ed.), Výchova ke zdraví: podněty ke vzdělávacím oblastem, 185-198, Brno: MU.

PPM Factum (2004). Češi a sport. Tisková zpráva. Dostupné z <http://www.factum.cz/114_cesi-a-sport>

Sekot, A. (2008). Sociologické problémy sportu. Grada Publishing a.s.

Schmermund, A. (2004). Cardiorespiratory Fitness. Importance of exercise for healthiness. Herz, 29(4), 365-72.

Šafr, J., Patočková, V. (2010). Trávení volného času v České republice ve srovnání s evropskými zeměmi. Naše společnost, 8 (2), 21-27.

Tahal, R. (2014). Komunikace značky prostřednictvím celebrit. Marketing \& komunikace, 24(2), $20-21$.

Thuot, S. M. (1995). College students'attitudes toward anticipated sport participation. Perceptual and motor skills, 80(1), 155-160.

Wannamethee, G., Shaper, A. G. (1992). Physical activity and stroke in British middle-aged men. British Medical Journal, 304, 597-601.

Wyznikiewicz-Nawracala, A. (1998). Differences between sport active and non-sport active women. Women in Sport \& Physical Activity Journal, 7(1), 125.

Zich, F., Unger, V. (1995). Postoje české veřejnosti k tělesné výchově a sportu. Tělesná výchova a sport mládeže, 61, 1-8. 